\title{
23. SEISMIC MODELING OF DIAGENETIC EFFECTS IN CENOZOIC MARINE SEDIMENTS AT DEEP SEA DRILLING PROJECT SITES 612 AND $613^{1}$
}

\author{
David Goldberg, Borehole Research Group, Lamont-Doherty Geological Observatory and Department of \\ Geological Sciences, Columbia University \\ Roy H. Wilkens, Earth Resources Laboratory, Massachusetts Institute of Technology \\ and \\ Daniel Moos, Borehole Research Group, Lamont-Doherty Geological Observatory ${ }^{2}$
}

\begin{abstract}
Velocity and density measurements at DSDP Sites 612 (slope) and 613 (rise) were obtained in the laboratory and by geophysical logging. Discrepancies between the laboratory and in situ measurements that can be attributed to porosity rebound vary more strongly with lithology than with depth.

The in situ velocity and density logs were used at both sites to generate synthetic vertical seismic profiles. Surface seismogram phases are traced to their origin depths and correlated with nearby common depth points from USGS seismic lines 25 and 35 . The resulting seismic stratigraphy is generally consistent with published interpretations. The correlation is poorer at Site 613, however, because of significant localized variations in bathymetry and sediment thickness in the $4-\mathrm{km}$ offset from line 35 .

Bulk density and compressional velocity logs show increases across a diagenetic boundary (porcellanite) in the middle Eocene sediments. The change is sharp at Site 612 and gradational at Site 613; this dissimilarity generates amplitude and phase differences between synthetic seismic reflections at the two sites. The correlation of this boundary with Reflector $\mathrm{A}^{\mathrm{c}}$ suggests that changes in physical properties may generate seismic reflections which cannot be simply related to lithologic changes or depositional times.
\end{abstract}

\section{INTRODUCTION}

Results of recent DSDP investigations along the seaward edge of the Baltimore Canyon Trough have substantially improved the interpretation of seismic data available to the research community. The depth correlation and lateral continuity of seismic reflectors in this region are still ambiguous, however. DSDP Leg 95 was designed to further improve seismic stratigraphy by well control in a transect across the continental margin. Sites 612 and 613 were drilled during Leg 95 and reliable geophysical logs were recorded. These logs constrain interpretations of the seismic results and aid in the delineation of vertical and lateral changes in lithology. In this chapter, the Cenozoic seismic stratigraphy is reinvestigated at both Leg 95 sites.

A quantitative geologic model of seismic reflections requires accurate determination of the compressional velocity and bulk density of the rock. The validity of the model is directly related to the reliability of these physical property measurements. Both measurements can be obtained in the laboratory and in situ. Unfortunately, measurements in the laboratory contain large errors resulting from drilling disturbance and dilatancy of the samples, and the depth control is limited by the percentage of core recovery. The in situ log measurements do

\footnotetext{
${ }^{1}$ Poag, C. W., Watts, A. B., et al., Init. Repts. DSDP, 95: Washington (U.S. Govt. Printing Office).

2 Addresses: (Goldberg and Moos) Borehole Research Group, Lamont-Doherty Geological Observatory, Columbia University, Palisades, NY 10964; (also for Goldberg) Department of Geological Sciences, Columbia University; (Wilkens) Earth Resources Laboratory, Massachusetts Institute of Technology, Cambridge, MA 02142.
}

not contain these uncertainties. Thus, the reliability of the physical property measurements is improved, and the relationship between geology and seismic reflections can be more accurately modeled through the use of log measurements.

\section{SEISMIC REFLECTION DATA}

U.S. Geological Survey (USGS) 48-fold seismic lines 25 and 35 were recorded by Geophysical Services, Inc. (GSI) in mid-1978 using a DFS IV recording system. Site 612 is approximately $0.1 \mathrm{~km}$ north of line 25 (Fig. 1), in $1414.3 \mathrm{~m}$ of water near shotpoint 3060 . Total penetration at this site was $675.3 \mathrm{~m}$ sub-bottom, which corresponds to about $2.6 \mathrm{~s}$ total two-way traveltime. Site 613 is approximately $4 \mathrm{~km}$ northwest of line 35 , in $2333 \mathrm{~m}$ of water near shotpoint 1445 ; total penetration was $581.7 \mathrm{~m}$, corresponding to about $3.8 \mathrm{~s}$ total two-way traveltime.

USGS line 25 is the most intensively studied dip line in the Baltimore Canyon Trough. The major reflections in line 25 seaward of the base of the slope typify the seismic-stratigraphic framework of the continental margin. Common depth point (CDP) traces from seismic line 25 near Site 612 and the Continental Offshore Stratigraphic Test (COST) B3 well are displayed in Figure 2. The major reflections apparent in the section have been thoroughly discussed in the literature (Tucholke, 1979; Tucholke and Mountain, 1979; Schlee, 1981). In general, the reflections correspond to lithologic changes and episodes of nondeposition or erosion. A widely correlated marker horizon (Reflector $\mathrm{A}^{\mathrm{c}}$ ) in the middle Eocene sediments is associated with the onset of silica diagene- 


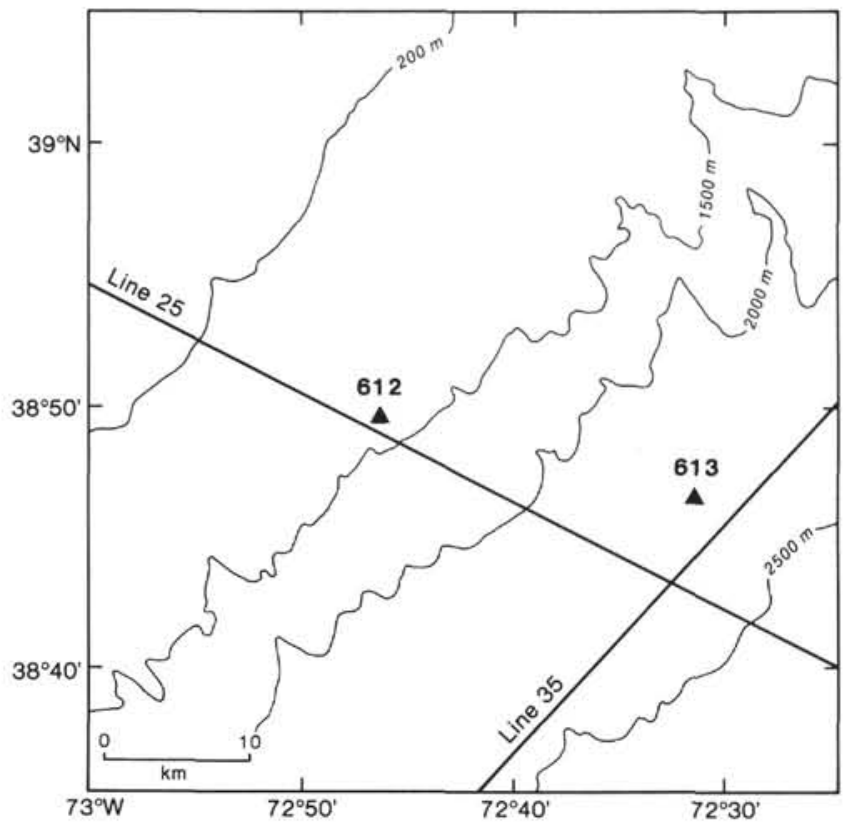

Figure 1. Map of Baltimore Canyon Trough showing locations of USGS seismic lines 25 and 35 and DSDP Sites 612 and 613 (after Robb et al., 1981).

sis from opal-A (biogenic) to opal-CT (porcellanite) (Weaver and Wise, 1974; Riech and von Rad, 1979). The porcellanite typically occurs near the lower Eocene/middle Eocene boundary, although it is not necessarily concordant with biostratigraphic changes.

Line 35 is aligned with the strike of the margin seaward of both DSDP sites (Fig. 1). CDP traces from seis- mic line 35 near Site 613 are displayed in Figure 3. Several seismic reflections, including Reflector $\mathrm{A}^{\mathrm{c}}$, can be traced to line 35 , suggesting that the horizons are continuous downslope. However, a simple correlation of reflections with lithologic boundaries (and subsequently with biostratigraphic ages) may oversimplify the stratigraphic relationships. Complex stratigraphic geometries may significantly affect reflections and vary over lateral distance. In this study, seismic modeling suggests that changes in Reflector $\mathrm{A}^{\mathrm{c}}$ occur between Sites 612 and 613.

\section{PHYSICAL PROPERTY MEASUREMENTS}

\section{Laboratory Data}

Porosity is measured in the laboratory by the weight difference between saturated and dry sediment samples. Bulk density is determined by dividing the sample wet weight by its volume. A detailed description of the technique and data is presented in the Site 612 and 613 chapters (this volume). The cross-plots of bulk density and porosity in Figures 4 and 5 summarize the results for 115 samples from Site 612 and 70 samples from Site 613. Each of the five lithostratigraphic units identified in the recovered core (Site 612 and 613 chapters, this volume) is represented by a different symbol.

The average grain density for each lithostratigraphic unit can be obtained by the zero-porosity intercept of a linear fit to these data. Lines of constant grain density spanning the range of values at each site are shown in Figures 4 and 5 . Grain density calculations $\left(\rho_{g}\right)$ by leastsquares regression in each lithostratigraphic unit are shown in Table 1. The grain density in these samples is deter-

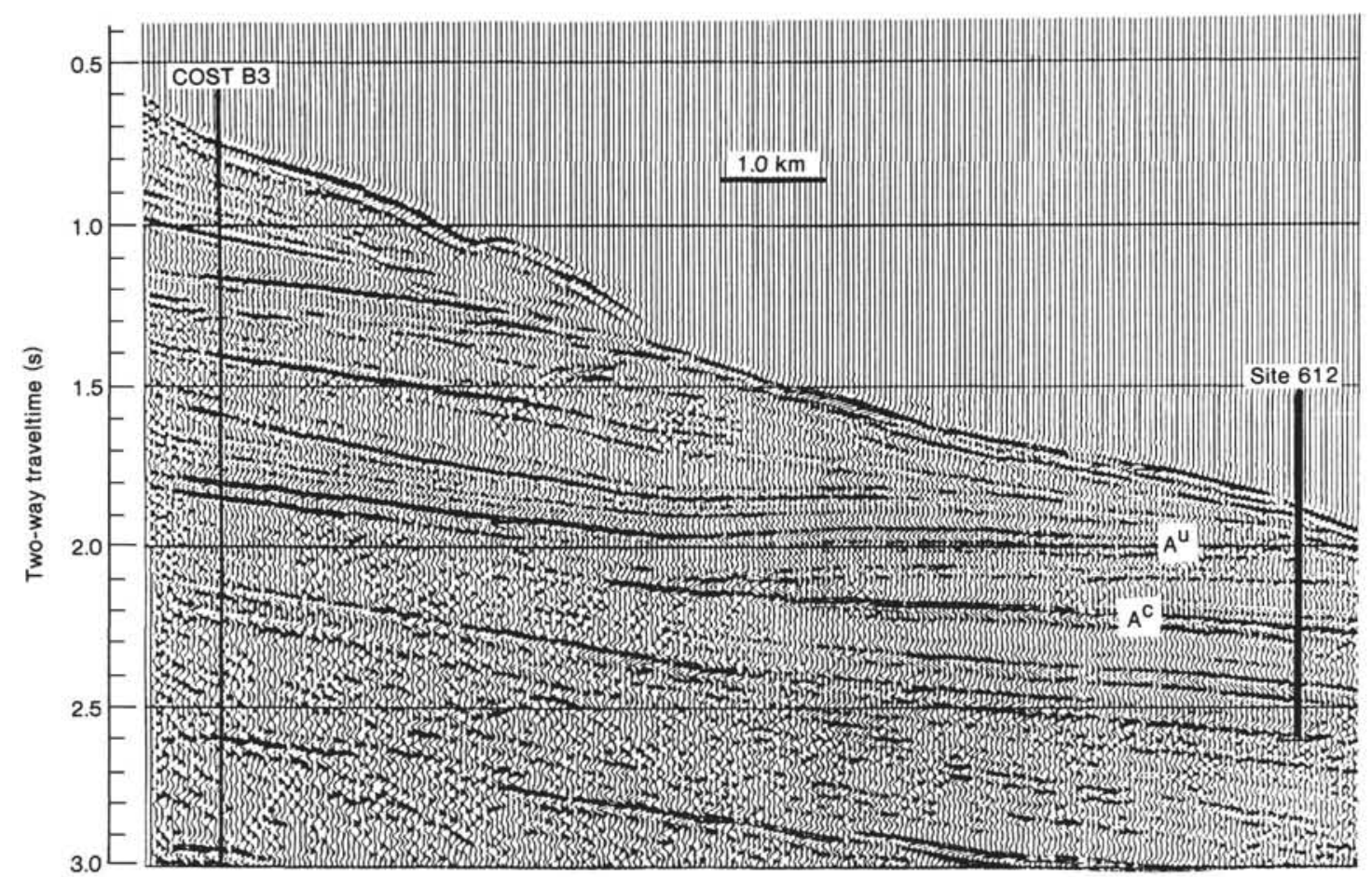

Figure 2. Site 612 and COST B3 projected to USGS seismic line 25 . Penetration to $675 \mathrm{~m}$ sub-bottom is approximately $2.6 \mathrm{~s}$ total two-way traveltime. 


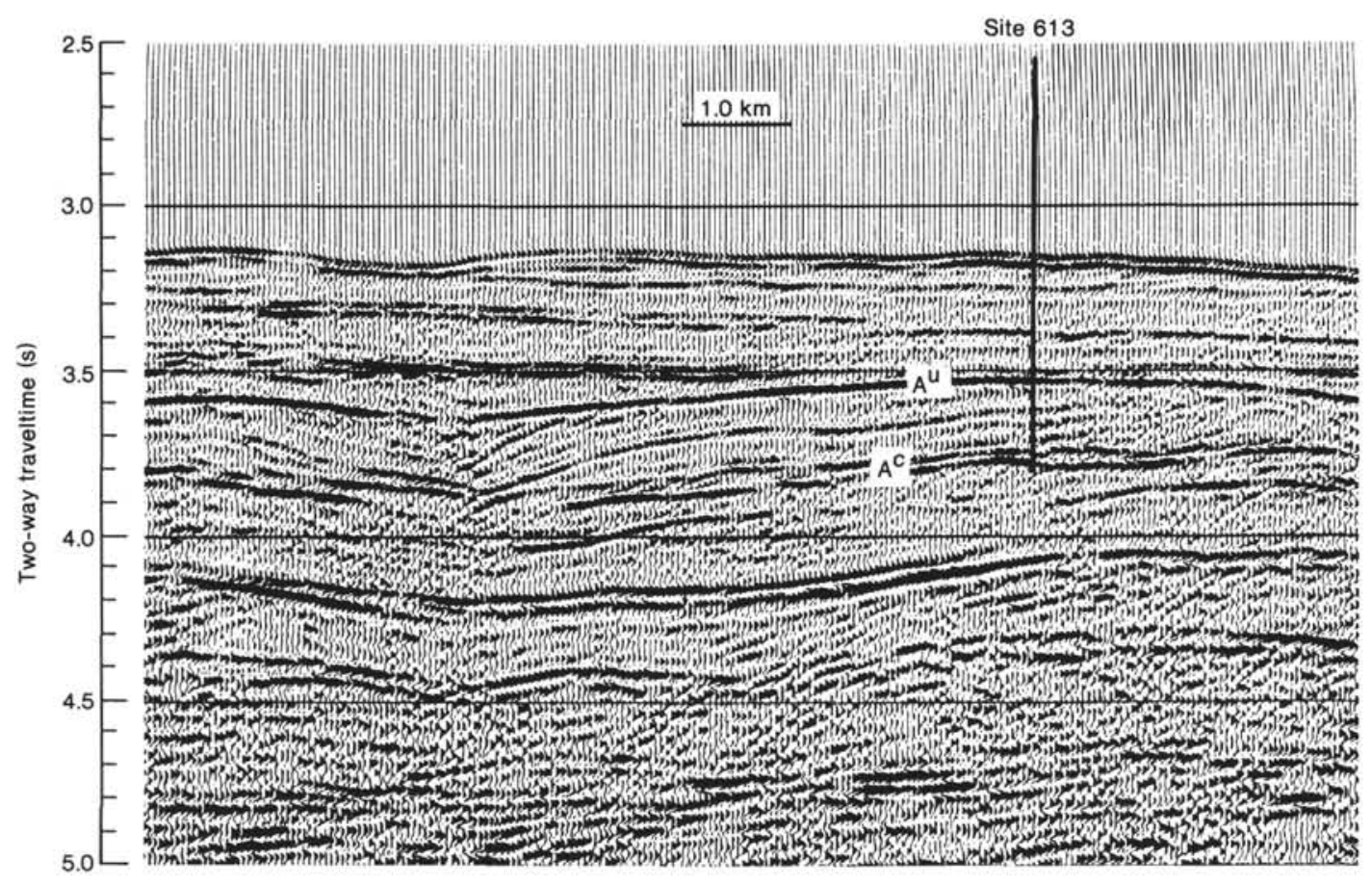

Figure 3. Site 613 projected to USGS seismic line 35 . Penetration to $585 \mathrm{~m}$ sub-bottom is approximately $3.8 \mathrm{~s}$ total twoway traveltime.

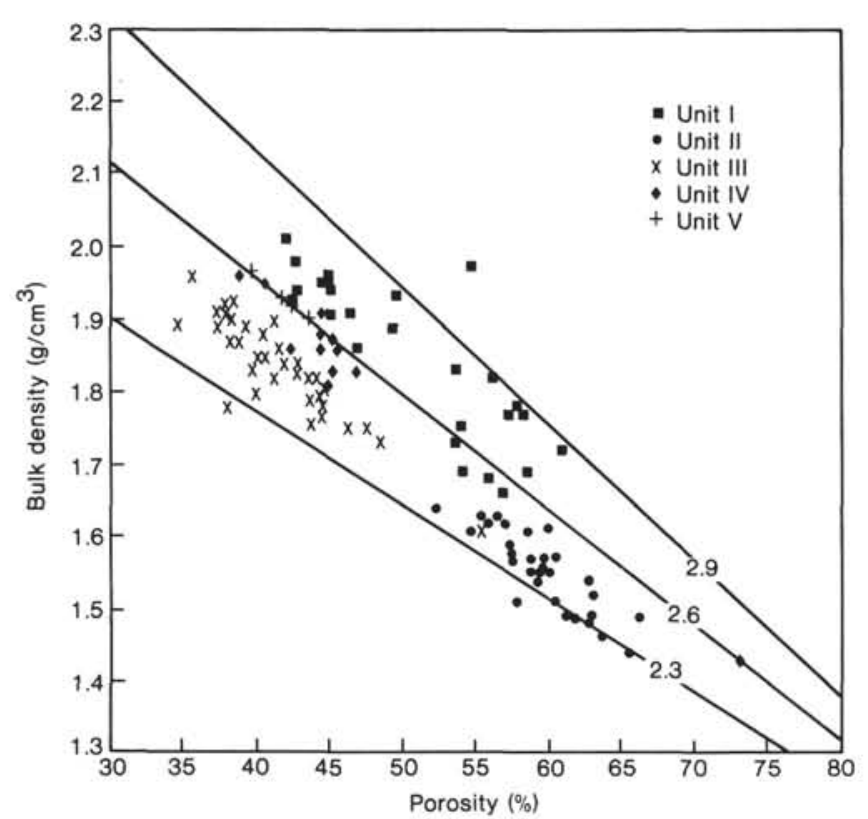

Figure 4. Shipboard measurements of bulk density versus porosity, Site 612. Symbols refer to lithostratigraphic units. Lines of calculated grain density are shown over the range of values for these data. Least-squares fit to the data for Units II and III yields grain densities of about $2.45 \mathrm{~g} / \mathrm{cm}^{3}$, corresponding to chemical composition $40 \%$ carbonate and $60 \%$ biogenic silica (see site chapters).

mined essentially by the relative proportions of carbonate $\left(\rho_{g}=2.71 \mathrm{~g} / \mathrm{cm}^{3}\right)$ and biogenic silica $\left(\rho_{g}=2.20 \mathrm{~g} /\right.$ $\mathrm{cm}^{3}$ ) in each lithostratigraphic unit. Note that the grain densities in corresponding units at Sites 612 and 613 agree to within about $3 \%$. However, the standard deviation of the grain density calculations varies between 3 and $8 \%$. Therefore, small differences in grain density between units,

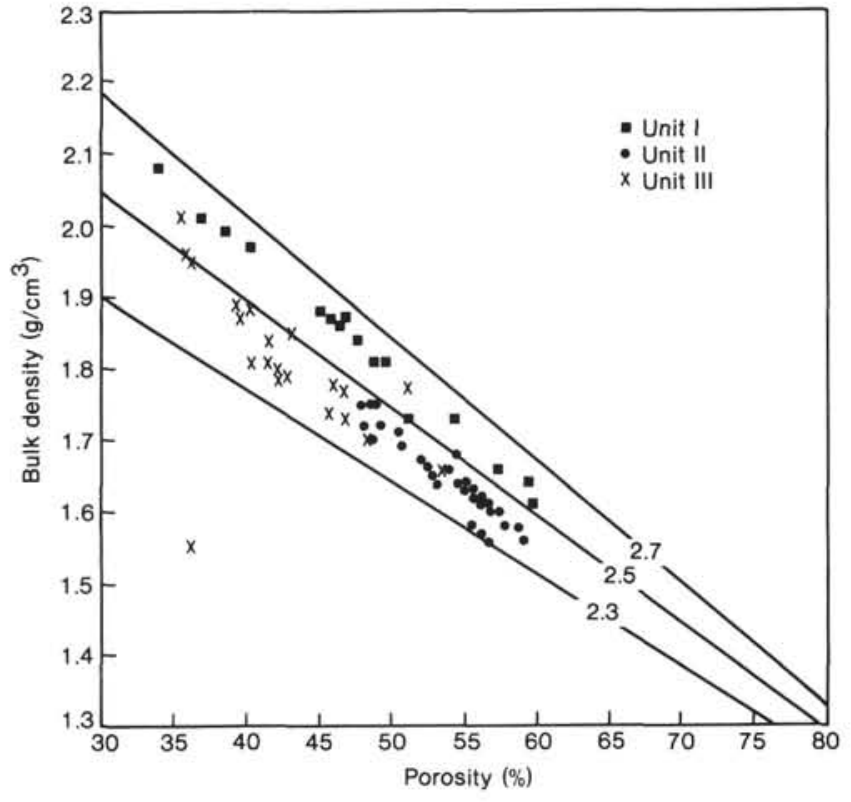

Figure 5. Shipboard measurements of bulk density versus porosity, Site 613. Symbols refer to lithostratigraphic units. Lines of calculated grain density are shown over the range of values for these data. Least-squares fit to the data yields grain densities of about $2.51 \mathrm{~g} / \mathrm{cm}^{3}$ for Unit II and about $2.43 \mathrm{~g} / \mathrm{cm}^{3}$ for Unit III. This corresponds to a higher carbonate content in Unit II.

such as Units II and III, cannot be effectively distinguished by this statistical technique.

\section{Comparison of Laboratory and in Situ Porosity}

The sediment porosity measured in the laboratory may be higher than in situ values because of expansion of the sample. This dilatancy results primarily from elastic re- 
Table 1. Grain densities $\left(\rho_{g}\right)$ calculated by leastsquares regression.

\begin{tabular}{lrrrrrrr}
\hline & \multicolumn{3}{c}{ Site 612 } & & \multicolumn{3}{c}{ Site 613 } \\
\cline { 2 - 3 } \cline { 6 - 8 } Unit & $\rho_{g}$ & $R$ & $N$ & & $\rho_{g}$ & $R$ & $N$ \\
\hline I & 2.612 & 0.699 & 26 & & 2.679 & 0.988 & 16 \\
II & 2.442 & 0.732 & 31 & & 2.512 & 0.892 & 32 \\
III & 2.469 & 0.786 & 38 & 2.428 & 0.872 & 22 \\
IV & 2.550 & 0.957 & 14 & & & \\
V & 2.648 & 0.988 & 6 & & & \\
\hline
\end{tabular}

Note: $R=$ coefficient of correlation; $N=$ number of samples.

bound after removal of the in situ overburden stress (Hamilton, 1976). Since the overburden stress increases with depth, the elastic rebound similarly increases, offset only by lithification of the sediment (Shipley, 1983). The depth at which lithification effects become important depends on the extent of diagenesis in the sediment column. Changes in lithology, however, also have significant effects on the elastic rebound (Hamilton, 1976). Mayer's (1984) calculated rebound correction factor for deep-sea carbonates predicts a $5.5 \%$ maximum porosity increase for samples raised from $400 \mathrm{~m}$ depth of burial. A previous comparison of in situ and laboratory measurements by Shipley (1983) has substantiated a porosity correction of $9 \%$ in different sediment types.

At Site 612, a formation density log was recorded. In this logging experiment, medium-energy gamma rays are emitted from a downhole source, collide with formation electrons, and lose energy because of the Compton scattering effect. The energy of recorded gamma rays is related directly to the electron density which, in turn, is related to the bulk density of the formation (Schlumberger, Ltd., 1972). Porosity is then calculated using the bulk density log and the average grain density of the formation obtained in the laboratory (Table 1). Hence, the porosity calculation is improved over standard techniques by using grain density measurements instead of an assumed matrix value.

The difference between laboratory and in situ porosity values at Site 612 is displayed versus depth in Figure 6 . The log values are plotted at depths coincident with laboratory measurements, and each lithostratigraphic unit is plotted using a different symbol. In situ and laboratory values agree to within about $10 \%$ as both generally decrease downhole. The difference between log and lab data does not continuously increase with depth of burial, though, but varies differently with depth in each lithostratigraphic unit. This suggests that elastic rebound depends more on lithology than on depth in these sediment samples.

\section{Sonic Porosity}

Porosity can also be empirically estimated using the compressional-wave velocity. This independent approach is useful in the absence of direct measurements. Sonic porosity has been empirically related to compressionalwave slowness in compacted sediments by using a timeaverage equation (Wyllie et al., 1958). The relationship

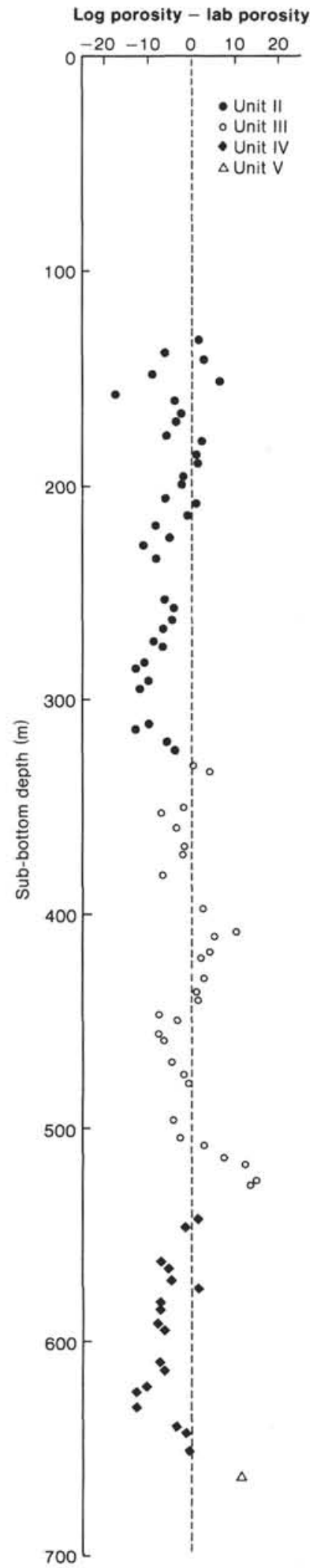

Figure 6. Calculated difference between in situ and laboratory porosity measurements in each lithostratigraphic unit, Site 612 (symbols). In general, in situ porosity is lower than laboratory porosity, owing to elastic rebound of the sediment samples (see text). However, this difference varies more strongly between units than with depth. 
is theoretically nonlinear, however, particularly at high porosities, as in uncompacted sediments (Wood, 1930; Officer, 1958; Shumway, 1960). Empirical relationships have also been defined to describe the results of laboratory experiments on various seafloor sediments (Hamilton, 1982). Figure 7 shows a plot of the compressionalwave slowness versus porosity for data from Site 612, together with plots of Hamilton and Bachman's (1982) results from continental shelf data, Wood's (1930) equation, and the time-average equation (Wyllie et al., 1958).

The apparent grouping of lithologies in Figure 7 suggests that the variation in velocity (reciprocal slowness) is controlled by changes in composition and porosity. Since the composition in Units II and III is similar (Table 1), the increase in velocity from Unit II to III can be attributed largely to increases in compaction and cementation. The data also range between the empirical curves for uncompacted and lithified sediments, as might be expected for partial lithification. Since Hamilton's relationship for carbonate shelf sediments is nearly linear in the limited 30 to $70 \%$ porosity range, the Unit II and Unit III data alone can be reasonably fit by a linear regression. The regression of slowness $(\Delta t$ in $\mu \mathrm{s} / \mathrm{m})$ as a function of porosity ( $\phi$ in decimal units) is given by

$$
\Delta t=360.5 \phi+363.4
$$

Using this relationship and the compressional-wave slowness, sonic porosity was calculated for Units II and III. A comparison of the Site 612 density and sonic porosity values is shown in Figure 8 . The data illustrate that sonic porosity is systematically higher than density porosity in Unit II. This is not surprising, since the assumption of a linear relationship between slowness and porosity breaks down at higher porosities. However, the

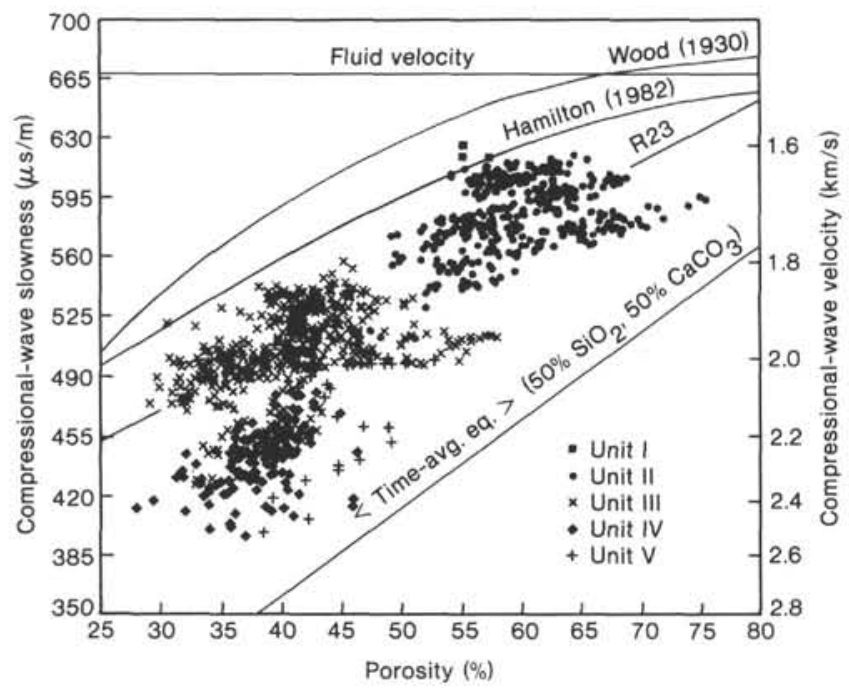

Figure 7. Traveltime (expressed as compressional-wave slowness) plotted versus $\log$ porosity calculated from bulk density and grain density for each unit, Site 612 . Line R23 is a least-squares regression to Unit II and Unit III, given by $\Delta t=360.5 \phi+363.4$. Also included are time-average (Wyllie et al., 1958) and shelf carbonate data (Hamilton and Bachman, 1982), and Wood's (1930) equation.

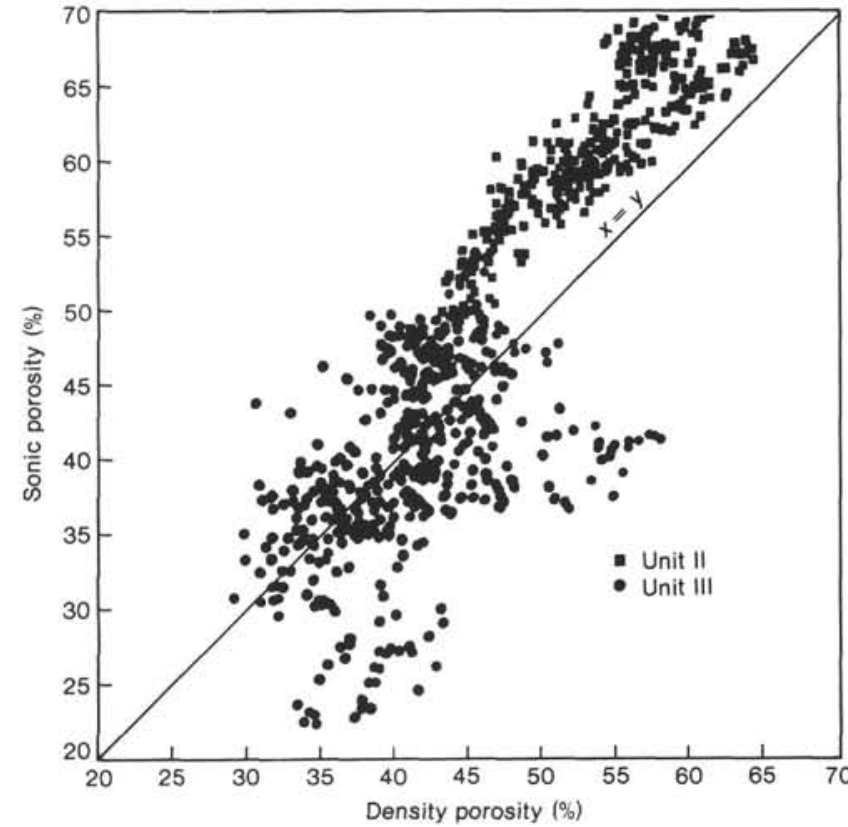

Figure 8. Comparison of porosity measurements in Units II and III at Site 612 from sonic and density logs. Sonic porosity is calculated from a least-squares fit (R23) to the data in Figure 7; density porosity is calculated from bulk density log and grain densities measured in the laboratory. Line corresponds to $x=y$. The sonic porosity is generally higher than the density porosity in Unit II. In Unit III, the data are scattered about $x=y$.

higher sonic porosity is consistent with laboratory porosity measurements in this interval.

Compressional velocity $(V p)$ and bulk density $\left(\rho_{b}\right)$ profiles at Site 612 are plotted in Figure 9. Plots of laboratory results (points), log data (light lines), and model values (heavy lines) are superimposed. In general, laboratory measurements are lower than the log values, because of expansion and disturbance of the laboratory samples. The most severe discrepancy is in Unit II. The model values are interval averages of the logs calculated to best match the raw data by varying the averaging interval between 2 and $10 \mathrm{~m}$. Averages were calculated to best match the laboratory data in the unlogged (cased) intervals of each well.

Figure 10 shows the compressional velocity and bulk density profiles at Site 613 . No density log was obtained at Site 613. Instead, the compressional-wave slowness log was used to estimate porosity by the empirical relationship (Eq. 1) determined from the Site 612 data. Site 613 bulk density was then calculated using this estimated porosity and Site 613 laboratory grain-density measurements. The resulting bulk density log and the laboratory measurements at Site 613 are consistent with the disparity between laboratory and log bulk-density measurements at Site 612 .

\section{SEISMIC MODELING}

To correlate surface seismic reflections with depth, a synthetic vertical seismic profile (VSP) was generated from the modeled velocity and density profiles and a seismic source at each site. The source used was the im- 


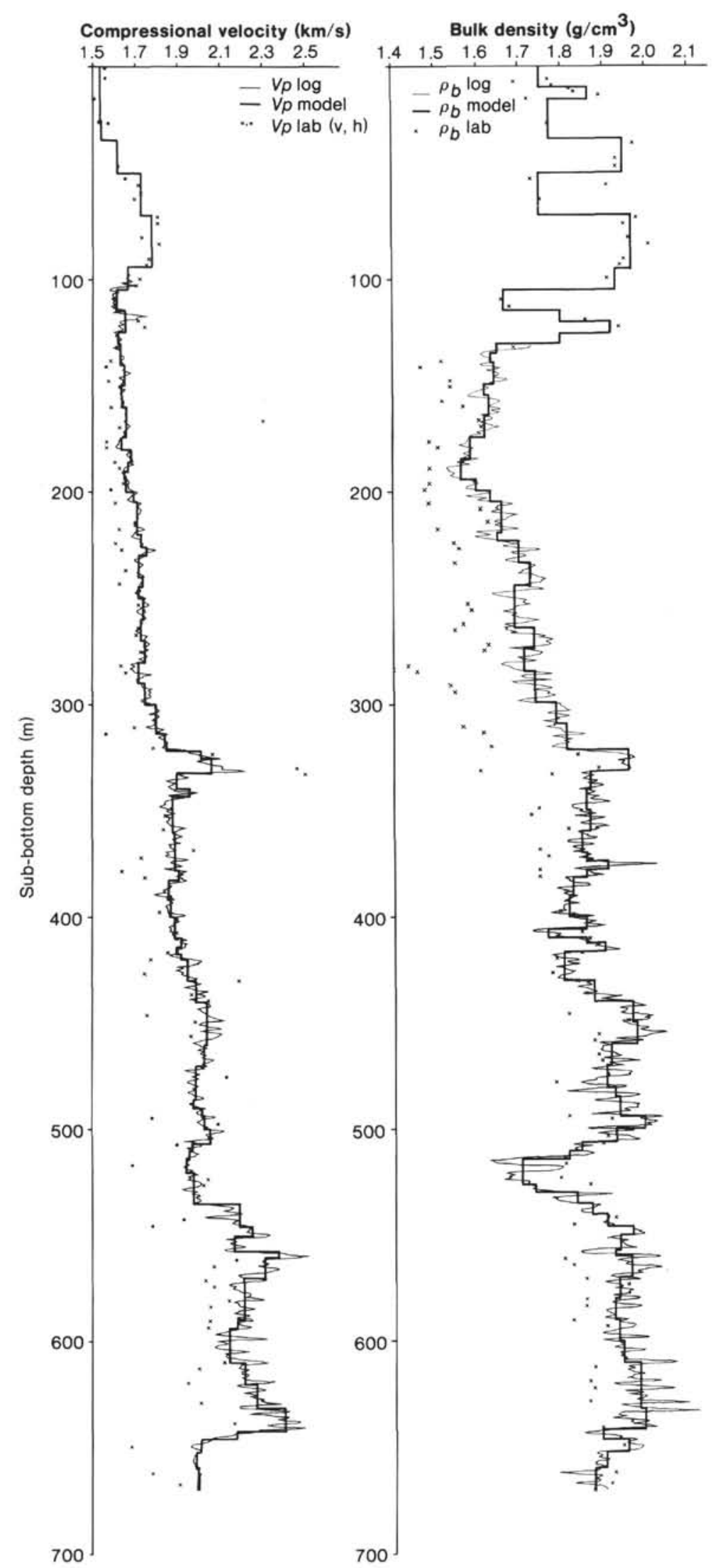

Figure 9. Overlay of shipboard, log, and interval-averaged compressional velocity $(V p)$ and bulk density $\left(\rho_{b}\right)$ for Site 612 . 


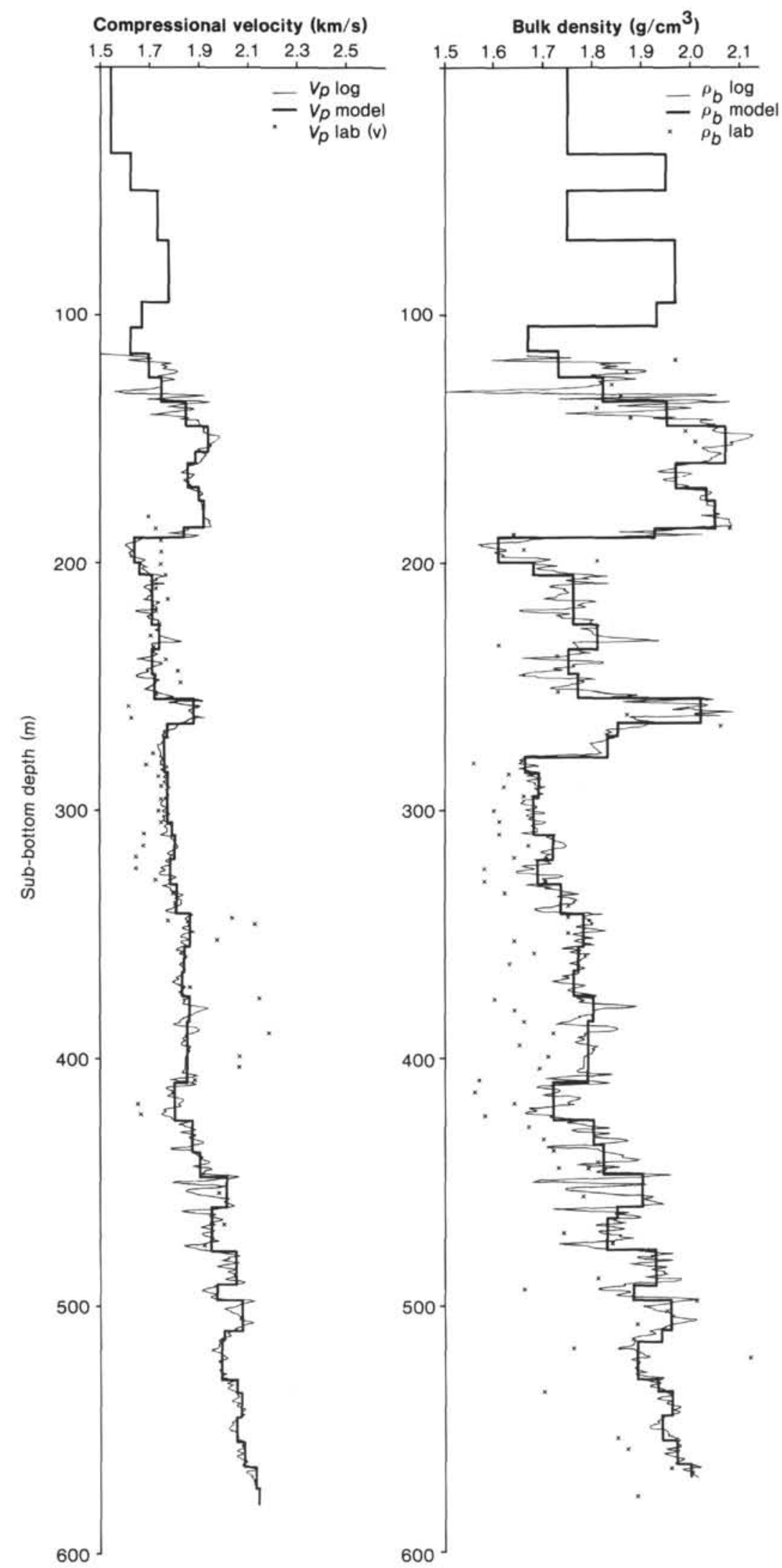

Figure 10. Overlay of shipboard, log, and interval-averaged compressional velocity $(V p)$ and bulk density $\left(\rho_{b}\right)$ for Site 613 . 
pulse response of the DFS IV recording system filter shown in Figure 11. The recording filter is assumed to dominate any bubble reverberations or other aberrations in the air-gun signal and to be uniform at each shotpoint. The low-cut filter setting was $8 \mathrm{~Hz}$ with cutoff at $3 \mathrm{~dB}$ down on an 18-dB/octave slope. The high-cut antialias setting was $62 \mathrm{~Hz}$ with cutoff at $70 \mathrm{~dB}$ down at one-half the sampling frequency $(125 \mathrm{~Hz})$ on a $-72-\mathrm{dB} /$ octave slope. These frequency limitations are shown graphically by the filter amplitude spectrum in Figure 12 (Texas Instruments, 1970). The filter has a nearly linear phase response within the usable bandwidth between 8 and $62 \mathrm{~Hz}$.

A synthetic VSP algorithm (Ganley, 1981; Moos, 1984) was used to calculate the seismic signal in the frequency

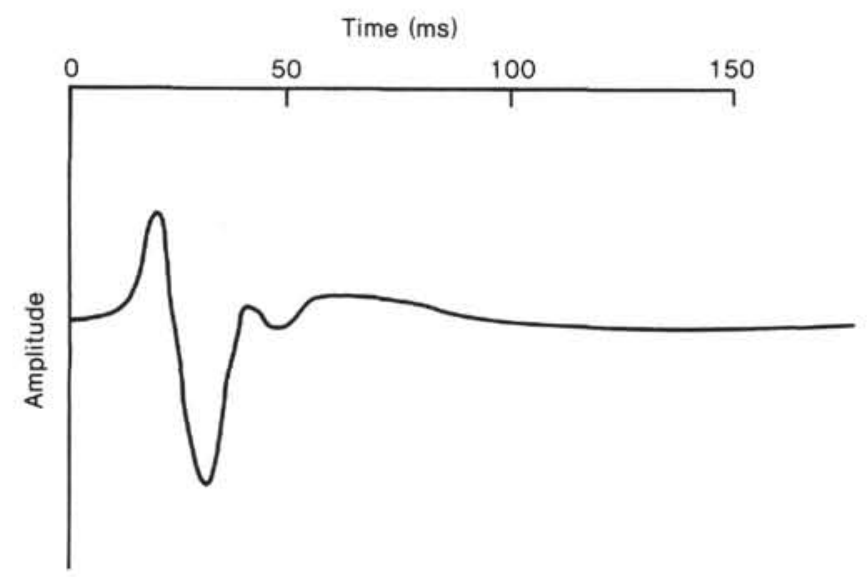

Figure 11. Impulse response of the seismic amplifier system used by Geophysical Services, Inc., in recording USGS lines 25 and 35. This is assumed to be the source signature for the seismic modeling in this study. Discrepancy of the actual source from this filter is due to nonuniform air-gun firings or bubble reverberations.

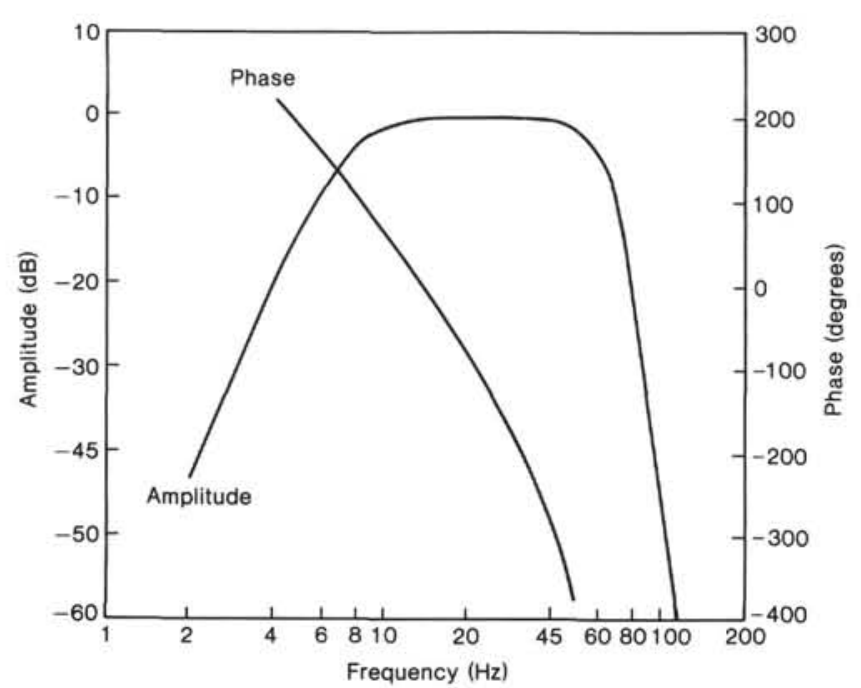

Figure 12. Amplitude and phase spectra of the source signature shown in Figure 11. Low-cut filter setting is at $8 \mathrm{~Hz}$ with cutoff at $3 \mathrm{~dB}$ down on an 18-dB/oct slope. High-cut alias filter is at $62 \mathrm{~Hz}$ and $70 \mathrm{~dB}$ down on an 72-dB/oct slope at one-half the sampling frequency $(125 \mathrm{~Hz})$. domain. Computation time and numerical accuracy of the synthetic is directly related to the number of depth intervals in the model. Models of less than 100 layers, of variable thickness, were chosen.

A reflection-coefficient series was first calculated at each frequency, using the velocity and density values from the physical property models. Then the synthetic amplitude of the wavefield was calculated at each interface, including the contributions from internal reflections. The method is one-dimensional and does not account for the effects of nonvertical incidence, geometrical spreading, or mode conversions. Because the synthetic is generated in the frequency domain, however, the effects of attenuation can be included. There is evidence for changes in sonic attenuation with depth (Goldberg et al., 1985). But the uncertainty in the frequency dependence of intrinsic attenuation precludes the extrapolation of these changes to seismic data. An intermediate and constant value of attenuation $(Q=200)$ was chosen for the synthetic over the entire depth interval.

The depth resolution of the synthetic is limited by the wavelength of the seismic source (about $100 \mathrm{~m}$ ). However, the amplitude and phase of seismic reflections are significantly affected by variation in structure on a finer scale (Widess, 1973; Schoenberger and Levin, 1976). In an idealized case, the total seismic response can be described by the sum of reflections from successive boundaries, expressed as a series of increasing-order time derivatives of the incident pulse (Widess, 1973; Stephens and Sheng, 1985). Therefore, seismic reflections may vary owing to the number or thickness of thin layers across a multiple-layer boundary.

\section{RESULTS}

Synthetic VSPs are shown in Figures 13 and 14 for Sites 612 and 613, respectively. Seismograms were calculated at depth intervals corresponding to the boundaries between lithostratigraphic units. By including these traces, several phases of the surface trace can be extrapolated back to their origin depths. Although reflection coefficients at each depth are directly related to the geologic model, a simple correlation is often complicated by internally reflected energy between intermediate boundaries. The depth to each seismic reflector can be determined by comparison of the surface synthetic with the nearby seismic section in Figure 15 or 16. Hence, at each site, seismic phases can be attributed to particular changes in physical properties in the sediments.

At Site 612, synthetic reflections match most phases in the seismic section in both relative amplitude and arrival time. At Site 613, the match is poorer. For the most part, discrepancies can be attributed to variation in the bathymetry and sediment thickness between the sites and the lines. The general upslope thinning of the sediment wedge can change the traveltime to a particular reflector by more than $0.1 \mathrm{~s}$ over a lateral offset of only a kilometer. Also, ancient and active erosion has created localized variations in sediment thickness. Because of these effects, the unfortunately large lateral offset of Site 613 from line 35 generates significant differences between syn- 


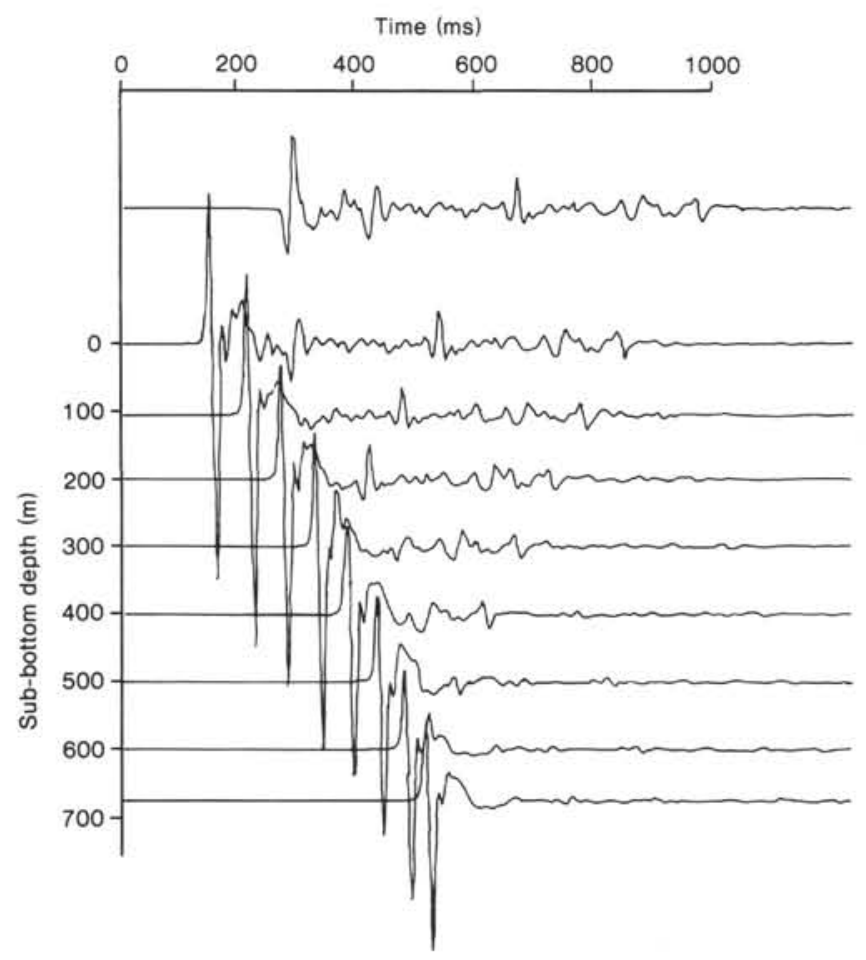

Figure 13. Synthetic vertical seismic profile (VSP) at Site 612. Averaged bulk density and compressional velocity logs with a constant value of seismic attenuation $(Q=200)$ were used. Surface seismogram phases correspond to earlier phases in subsurface seismograms, owing to shorter travel paths from source to receiver. Hence, surface reflections can be traced to their depths of origin.

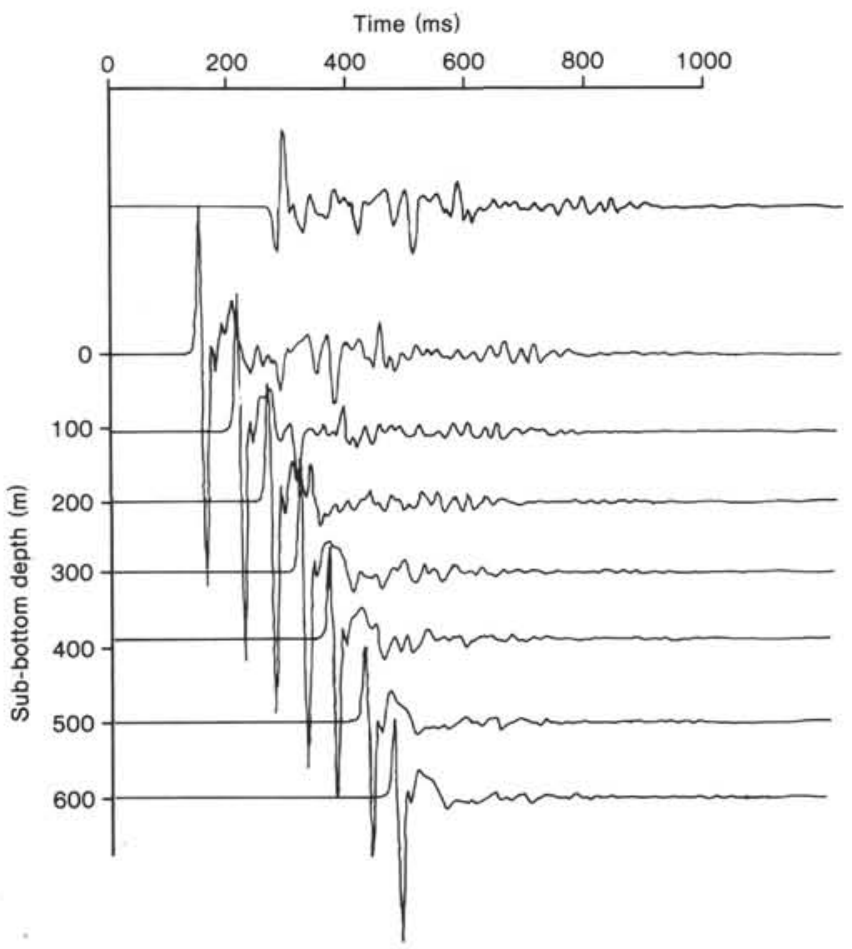

Figure 14. Synthetic VSP at Site 613. Estimated bulk density and averaged compressional velocity logs with a constant value of seismic attenuation $(Q=200)$ were used.

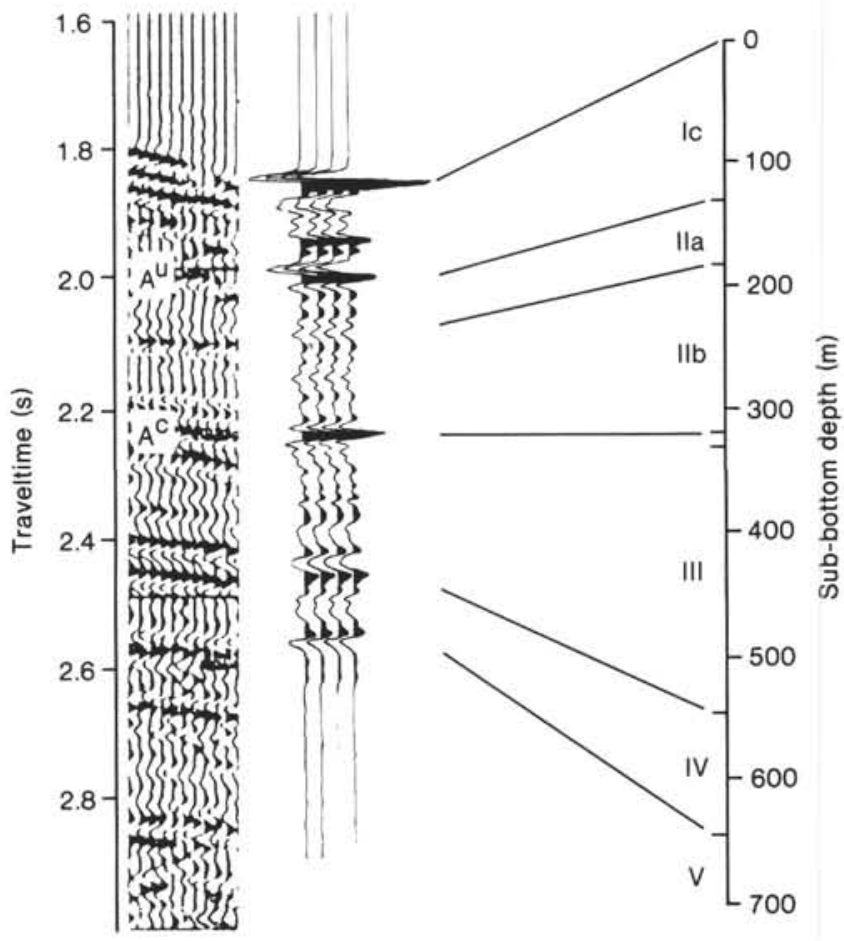

Figure 15. Correlation of surface synthetic seismograms with depth at Site 612. Model seismogram is correlated with depth using the synthetic VSP at lithostratigraphic unit boundaries observed in the core. Approximate time correlation is shown next to the seismic section from line 25 . In general, reflectors at Site 612 are well correlated with lithostratigraphic boundaries observed in the core.

thetic reflections and the seismic section. An approximate alignment of the synthetic with the section in Figure 16 is tied by the large impedance contrast at the Unit I/Unit II boundary (Eocene/Miocene) and the high-amplitude reflection (Merlin/ $\mathrm{A}^{\mathrm{u}}$ ) at $3.53 \mathrm{~s}$ total traveltime (G. Mountain, personal communication, 1985). The mismatch of the synthetic with other events is then minimized.

The lithostratigraphic boundary between Units II and III was identified by the occurrence of porcellanite in the sediments (Site 612 and 613 chapters, this volume). Porcellanite results from the dissolution of siliceous microfossils and their subsequent reprecipitation as intergranular cement in the form of lepispheres (Wise and Weaver, 1974; Wilkens et al., this volume). The physical properties across this diagenetic boundary change between Sites 612 and 613. At Site 612, the boundary was modeled as a discrete high-velocity and high-density layer at the top of the porcellanite ( $324 \mathrm{~m}$ sub-bottom). One explanation of this pronounced layer is that cementation was intensified as a result of high pore-water salinity (Site 612 and 613 chapters, this volume). A highamplitude synthetic reflection was generated. At Site 613, a gradational boundary ( $442 \mathrm{~m}$ sub-bottom) was modeled by incremental increases in velocity and density that generate a moderate-amplitude synthetic reflection. In addition, the phase of the synthetic reflection is different at each site. This observation results in part from the seismic response of a single-layer boundary at Site 612 , 


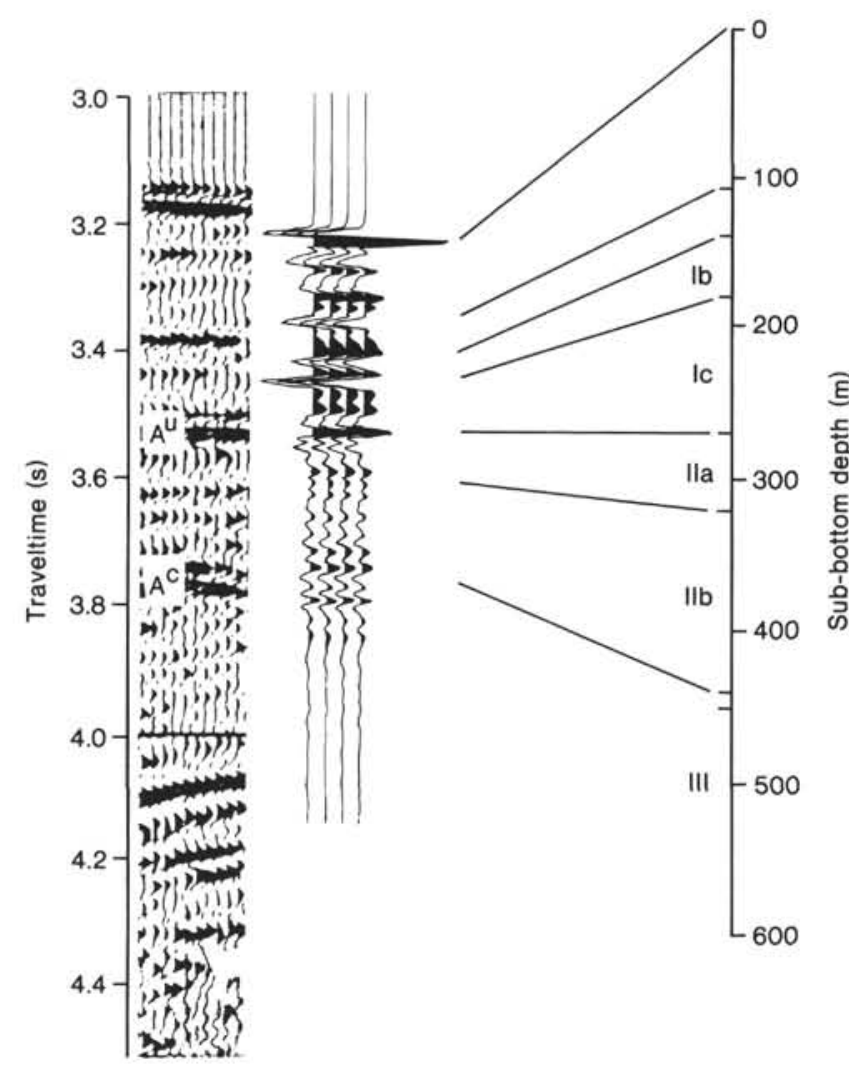

Figure 16. Correlation of surface synthetic seismograms with depth at Site 613. Model seismogram is correlated with depth using the synthetic VSP at lithostratigraphic unit boundaries observed in the core. Approximate time correlation is shown next to the seismic section from line 35. In general, reflectors at Site 613 are later (deeper) than boundaries observed in the core. This is attributed to dipping reflectors, offset from the line, variable sediment thickness, and uncertainties in the upper portion of the geologic model.

as against a multiple-layer boundary at Site 613. The actual boundary at both sites is oversimplified by the models, however, and the seismic differences may be due to even finer-scale variations.

\section{CONCLUSIONS}

The difference between in situ and laboratory measurements of bulk density is more strongly dependent on lithology than on depth of burial. In lieu of a density $\log$, a reliable estimate of in situ bulk density was calculated for Site 613 by using a linear regression of compressional slowness and porosity data at Site 612 . Synthetic VSP seismograms were calculated from interval averages of the logs at both sites, which made possible accurate determination of the origin depths of surface seismogram phases. Owing to variations in bathymetry and sediment thickness, the correlation is poor between synthetic seismograms at Site 613 and seismic line 35 .

The contrast in physical properties at the diagenetic boundary between Units II and III is sharp at Site 612 and gradational at Site 613; this difference generates amplitude and phase differences between seismic reflections (Reflector $\mathrm{A}^{\mathrm{c}}$ ) at the two sites. From this observation, changes in physical properties over lateral distances may generate seismic reflections which cannot be simply related to lithologic changes or depositional times.

\section{ACKNOWLEDGMENTS}

David Goldberg and Dan Moos were supported in part during this work by the National Science Foundation and the Joint Oceanographic Institutions under contract JOI 66-84. Roy Wilkens was supported in part by the National Science Foundation under grant 8408761-OCE.

\section{REFERENCES}

Ganley, D. C., 1981. A method for calculating synthetic seismograms which include the effects of absorption and dispersion. Geophysics, 46:1100-1107.

Goldberg, D. S., Moos, D., and Anderson, R. N., 1985. Attenuation changes due to diagenesis in marine sediments. Trans. 26th Ann. SPWLA Symp., paper KK.

Hamilton, E. L., 1956. Low sound velocities in high-porosity sediments. J. Acoust. Soc. Am., 28:16-19.

1976. Variations of density and porosity with depth in deepsea sediments. J. Sediment. Petrol., 46:280-300.

Hamilton, E. L., and Bachman, R. T., 1982. Sound velocity and related properties of marine sediments. J. Acoust. Soc. Am., 72(6): 1891-1904.

Mayer, L. A., 1980. Deep-sea carbonates: Physical property relationships and the origin of high frequency acoustic reflectors. Mar. Geol., 38:165-183.

Moos, D., 1984. A case study of vertical seismic profiling in fractured crystalline rock. In Simaan, M. (Ed.), Advances in Geophysical Data Processing (Vol. 1): Greenwich, CT (JAI Press), 9-37.

Officer, C. B., 1958. Introduction to the Theory of Sound Transmission: New York (McGraw-Hill), p. 257.

Riech, V., and von Rad, U., 1979. Eocene porcellanites and Early Cretaceous cherts from the western North Atlantic basin. In Tucholke, B. E., Vogt, P. R., et al., Init. Repts. DSDP, 43: Washington (U.S. Govt. Printing Office), 437-448.

Robb, J. M., Hampson, J. C., Kirby, J. R., and Twitchell, D. C., 1981. Geology and potential hazards of the continental slope between Lindenkohl and South Toms canyons, offshore mid-Atlantic United States. U.S. Geol. Surv. Open File Rept., 81-600:1-38.

Schlee, J. S., 1981. Seismic stratigraphy of the Baltimore Canyon Trough. Am. Assoc. Pet. Geol. Bull., 65:26-53.

Schlumberger, Ltd., 1972. The formation density log. Schlumberger Log Interpretation (Vol. 1): Principles, 43-48.

Schoenberger, M., and Levin, F., 1976. Reflected and transmitted filter functions for simple subsurface geometries. Geophysics, 41: 1305-1317.

Shipley, T. H., 1983. Physical properties, synthetic seismograms, and seismic reflection correlations at DSDP Site 534, Blake-Bahama Basin. In Sheridan, R. E., Gradstein, F. M., et al., Init. Repts. $D S D P, 76$ : Washington (U.S. Govt. Printing Office), 653-665.

Shumway, G., 1960. Sound speed and absorption studies of marine sediments by a resonance method. Geophysics, 25:451-467, 639682.

Stephens, R. B., and Sheng, P., 1985. Acoustic reflections from complex strata. Geophysics, 50:1100-1107.

Texas Instruments, 1970. Record filter response. DFS Performance Manual, pp. 1-17.

Tucholke, B. E., 1979. Relationships between acoustic stratigraphy and lithostratigraphy in the western North Atlantic basin. In Tucholke, B. E., Vogt, P. R., et al., Init. Repts. DSDP, 43: Washington (U.S. Govt. Printing Office), 827-846.

Tucholke, B. E., and Mountain, G. S., 1979. Seismic stratigraphy, lithostratigraphy, and paleosedimentation patterns in the western North Atlantic Basin. In Talwani, M., Hay, W. W., and Ryan, W. B. F. (Eds.), Deep Drilling Results in the Atlantic Ocean: Continental Margins and Paleo-environment: Washington (Am. Geophys. Union), Maurice Ewing Series, 3:58-86.

Weaver, F. M., and Wise, S. W., 1974. Opaline sediments of the SE coastal plain and Horizon A: Biogenic origin. Science, 184:899901. 
Widess, M. B., 1974. How thin is a thin bed? Geophysics, 38:11761180.

Wise, S. W., and Weaver, F. M., 1974. Chertification of oceanic sediments. In Hsü, K. J., and Jenkyns, H. C. (Eds.), Pelagic Sediments: On Land and Under the Sea (Vol. 1): London (Blackwell Sci. Publ.), 301-326.

Wood, A. B., 1930. A Textbook of Sound: London (G. Bell and Sons).
Wyllie, M. R. J., Gregory, A. R., and Gardner, G. H. F., 1958. An experimental investigation of factors affecting elastic wave velocities in porous media. Geophysics, 23:459-493.

Date of Initial Receipt: 4 March 1985

Date of Acceptance: 16 September 1985 